\title{
'To Believe In This World, As It Is': Immanence and the Quest for Political Activism
}

\author{
Kathrin Thiele Utrecht University
}

\begin{abstract}
In What is Philosophy?, Deleuze and Guattari make the claim that '[i]t may be that believing in this world, in this life, becomes our most difficult task, or the task of a mode of existence still to be discovered on our plane of immanence today. This is the empiricist conversion.' What are we to make of such a calling? The paper explicates why and in what sense this statement is of exemplary significance both for an appropriate understanding of Deleuze's political thought and for a most timely conceptualisation of politics in a world so clearly defined by immanence, and nothing but immanence. I argue that Deleuze's rigorously constructive approach to the world is not beyond politics, as some recent readings have declared (e.g. those of Badiou and Hallward). Rather, we have to appreciate that in Deleuze and Guattari's demand for a 'belief in this world' the political intersects with the dimension of the ethical in such a way that our understanding of both is transformed. Only after this 'empiricist conversion' can we truly think of a Deleuzian politics that does justice to a plane of immanence 'immanent only to itself'.
\end{abstract}

Keywords: immanence, ethics, politics, transcendental empiricism, Badiou, Foucault, Spinoza

\section{Deleuze and the Political}

Writing on Deleuze and the question of politics does not really entail venturing into terra incognita. Given that so many founding thinkers

Deleuze Studies Volume 4: 2010 supplement: 28-45

DOI: $10.3366 / \mathrm{E} 175022411000111 \mathrm{X}$

(C) Edinburgh University Press

www.eupjournals.com/dls 
in the Deleuzian legacy have already engaged with this theme, the indebtedness of one's argument and thought to others is inevitably unending. ${ }^{1}$ However, looking at the many recent publications in what is called 'theory' in general, and in the vicinity of a Deleuzian philosophical horizon in particular, the question of politics stands out again and calls for renewed attention. Regarding Deleuzian scholarship in particular, the question is how things stand with Deleuze and politics now - after a first global round of philosophical reception of his philosophy. Can we really envision and concretise a Deleuzian political activism, a becomingactive so badly needed in relation to today's political state of affairs? Is there really a 'Deleuzian Politics', and if so, what does it look like?

When so many are calling for new political solutions, the question concerning the becoming-active of philosophical thought is not just one question amongst others. Rather, in times like these it becomes a question touching on the very legitimacy of a philosophical thought as such, that is, it becomes the criterion for measuring how and in what ways it relates to the world we are currently living in, and-most of all-to the world 'we are about to change'. So when, in 2006, Peter Hallward concluded his book on Deleuze, Out of This World: Deleuze and the Philosophy of Creation, with the statement that '[f]ew philosophers have been as inspiring as Deleuze. But those of us who still seek to change our world and to empower its inhabitants will need to look for our inspirations elsewhere' (Hallward 2006: 164), he was expressing only what our current situation seems so utterly determined by: change - at whatever cost.

This slightly ironical remark-which, I hope, will serve its purpose in this article-should, however, not give the impression that I disagree with Hallward's urge to relate thought and life. The times really are what they are, and Deleuzian trajectories are both needed and asked for. ${ }^{2}$ In considering how to respond to the question as to what kind of politics the Deleuzian universe suggests, there is at least one answer that can be ruled out immediately: if what is meant by politics involves an axiomatic of categorical prescriptions, then no, there is no 'Deleuzian Politics'; there is in Deleuze's thought neither a set programme nor recourse to prescription. While this may not seem to be such big news given the wellknown turn towards micropolitics in Deleuze and Guattari, one has to put emphasis on this moment of saying 'no'. Right at the beginning of the argument to be presented here it is important to stress that what is truly political in Deleuze and Guattari has less to do with what they stood up for than with how they managed to turn away from, and thus radically expose, the ways in which the question of politics itself 


\section{Kathrin Thiele}

is usually phrased. ${ }^{3}$ In Deleuze and Guattari, politics is not discussed according to the kind of frameworks we are normally used to: neither normative or moral principles, nor a concern for justice, equality and freedom, nor any attempt to choose between or attempt to harmonise these conflicting categories, represents the frame in which they conceive of politics. Instead, in accordance with a very Spinozan realism, ${ }^{4}$ the function of the term 'politics' in Deleuze and Guattari is, first of all, to stand in for the 'all there is' as such: politics - first of all-is nothing but the name of the force-relations, the milieu, and strata of everything that exists, the always already yet never once and for all territorialised regime,${ }^{5}$ the actualised plane of immanence which, however manifold in the virtual, only ever comes politically distributed. This is why Deleuze and Guattari, in A Thousand Plateaus, declare that 'politics precedes being', but also that, '[i]n short, everything is political, but every politics is simultaneously a macropolitics and a micropolitics' (Deleuze and Guattari 1987: 203, 213). From the affective structure of individual bodies to the structure of state-formations and beyond, everything is political in the sense that what 'there is' is a result of struggles between divergent forces, a result that shows greater or lesser stability and that can never definitively be fixed once and for all. ${ }^{6}$

This attitude towards politics comes very close to that of Michel Foucault, whose portrait as a political thinker likewise remains a contested one, and who also exemplifies this different approach, in particular in his lecture on 'Security, Territory, Population' at the College de France in 1978 (the famous course on biopolitics). There, Foucault explicitly presents his investigation as a philosophical inquiry, but that is an inquiry into 'the politics of truth', for, as he says, 'I do not see many other definitions of the word "philosophy" apart from this'. Since this is how he wants his undertaking to be understood, he rejects every sort of imperative discourse 'that consists in saying "love this, hate that, this is good, that is bad, be for this, beware for that"', and he most poignantly ends his enumeration with the following statement: 'So in all of this I will therefore propose only one imperative, but it will be categorical and unconditional: Never [do politics]' (Foucault 2009: 3-4). ${ }^{7}$

In framing my argument, however, with reference to this statement of Foucault's, am I not merely confirming Hallward's criticism of Deleuze, a criticism shared also by Alain Badiou who in his second opus magnum, Logics of Worlds: Being and Event II, states that 'Deleuze... came to tolerate the fact that most of his concepts were sucked up... by the doxa of the body, desire, affect, networks, the multitude, nomadism and enjoyment into which a whole contemporary "politics" sinks, as 
if into a poor man's Spinozism' (Badiou 2009: 35)? Is it not true then that Deleuze's philosophical gesture, rather than helping 'to change our world', simply leads 'out of this world'? Of course, this is not the conclusion to be drawn here, and what I hope to achieve in what follows will involve elaborating and unfolding the above mentioned alternative approach to political thinking in Deleuze: a becoming-active of philosophy which, in its concern for practice, requires a becomingactive in this world.

\section{II. 'To Believe In This World, As It Is': Deleuze's Practical Philosophy of Immanence}

In the face of heightened political expectations in many of today's philosophical discourses, it is important to take a step back and investigate the concepts themselves, to identify where they are located in the thought at stake, and how they function within this thought. In making use of one of Deleuze and Guattari's most central statements - the ethico-political demand for 'a belief in this world'-I would like to explicate how their thought intervenes into this world beyond any oppositional staging of the political concern that, as it seems right now, too many theoretical debates believe to be the only truthful one. ${ }^{8}$ In developing such a reading of politics, it is important to operate on different levels: First, we have to adequately understand the rigorous philosophical demand for an immanence immanent only to itself that is so fundamental to Deleuze's thought. His strong commitment to immanence and nothing but immanence already turns every ontological endeavour into a practical one, and that is into an endeavour driven by an ethico-political impetus. It is only when we have reached this Spinozan cross-over of ontology and ethics that we can move further and inquire into more concrete political directions.

\section{First Formula of Immanence: Ontology=Ethics}

In What is Philosophy?, Deleuze and Guattari give us a first version of the statement of 'belief in this world': 'It may be that believing in this world, in this life, becomes our most difficult task, or the task of a mode of existence still to be discovered on our plane of immanence today. This is the empiricist conversion' (Deleuze and Guattari 1994: 75). If we take the demand for a 'belief in this world' as Deleuze's formula for addressing the question of immanence in its full ethicopolitical potential, then we have to understand that this thought is 


\section{Kathrin Thiele}

first of all announced as a 'task', even a 'most difficult task'. It is phrased as a radical shift, a turn away from what we are used to think, and think thought to be, and it is this that they call the 'empiricist conversion'-conversio, a turning, with a long philosophical heritage from St Augustine to the American philosopher Ralph Waldo Emerson. ${ }^{9}$

Earlier in What is Philosophy?, Deleuze and Guattari also say that 'the entire history of philosophy [can] be presented from the viewpoint of the instituting of a plane of immanence' (Deleuze and Guattari 1994: 44). Yet, they continue, even today '[i]mmanence can be said to be the burning issue of all philosophy' (45). And this is so because immanence 'takes on all the dangers that philosophy must confront, all the condemnations, persecutions, and repudiations that it undergoes' (45). This difficult heritage - we have to remember that Spinoza, their 'prince of philosophy' when it comes to immanence, was accused of the severest heresy-produces confusions, and instead of being thought in itself, i.e. as an immanence immanent only to itself, immanence in most of philosophy's history is related to something else that contains it: ' $[R]$ ather than this substance of Being or this image of thought being constituted by the plane of immanence itself, immanence will be related to something like a "dative," Matter or Mind' (44). Immanence is handed over to a transcendent frame, and the movement, the infinite movement that only a thought of pure immanence ('the empiricist conversion') enables the world to become, is stopped again. Movement and tendencies (to use a Bergsonian concept), or longitudes and latitudes (the Spinozan equivalent), in short 'the world' conceptualised immanently, is again brought to a halt and the dynamic plane of immanence is referred back to static verticality. Hence the claim: 'Whenever there is transcendence, vertical Being, imperial State in the sky or on earth, there is religion; and there is Philosophy whenever there is immanence' (43).

If immanence is the true business of philosophy-of a philosophy worthy of its name, finally 'mature enough' (Deleuze and Guattari 1994: 48) - and as such entails a truly difficult task, it would be wrong to assume that thinking immanence merely means substituting new terms, while the image of thought-that which thinking is believed to be-remains untouched. Most of the time, the transcendent-from its most commonsensical version as 'what everybody knows' to its most abstract a priori structure as universal law - is re-introduced into our ways of thinking. It is re-introduced both on the level of what is thought and on the level of what thought itself 'is'. What is not taken into account is that thinking immanence as immanent only to itself not only changes the linguistic registers of thought, but does something to the act 
of thinking such thought itself. This is the essential 'active' dimension of Deleuze's and Guattari's claim 'to create' and 'to invent' concepts. Everything is affected in this turn, because '[i]mmanence is immanent only to itself and consequently captures everything, absorbs All-One, and leaves nothing remaining to which it could be immanent' (45).

It is necessary to dwell a little further on this. In order to grasp this change of register for thought itself - a change in both its terminological and its practical dimensions - the notion of empiricism as linked to the Deleuzian concept of 'belief' needs further explication. Here it is fruitful to come back to the specific 'American' atmosphere of Deleuze's thinking and in particular to William James' early description of pragmatism as a radical empiricism in which, as Deleuze writes in his essay on 'Bartleby, or the Formula', it 'was also necessary for the knowing subject, the sole proprietor, to give way to a community of explorers, the brothers of the archipelago, who replace knowledge with belief' (Deleuze 1997: 87). It is via such superior empiricism - to read James alongside Bergson - that the demand for a 'belief in this world', as a 'most difficult task' that also implies a different practice of thinking itself, is best captured. ${ }^{10}$ Thinking the world differently, when 'belief in' replaces 'knowledge of' the world, turns the world from something given into something to be explored, always to be constructed and created, and this again not according to the measure of 'what is' but according to the measure of 'what this world is capable of'. ${ }^{11}$ What such a thought implies - at the very heart of it -is an ethos, an active and affirmative attitude towards the world (how to construct otherwise?); and Deleuze, in the context of discussing American pragmatism, also names its ingredients: truth and trust, hope and confidence - 'not belief in another world, but confidence in this one, in man as much as in God' (Deleuze 1997: 87). Relating the ethico-political dimension thus to the ontological undertaking is what a rigorous thought of immanence generates and where-one could say in a most Emersonian way -it truly turns away and averts itself from the conventions of thought, so that not only what is thought (the world) becomes something else, but thought itself becomes ... $a$ world.

\section{Second Formula of Immanence: 'A Belief In This World, As It Is'}

Let us turn to a second version of Deleuze's demand for a belief in this world. This time the expression is taken from Deleuze's Cinema 2: The Time-Image, and it is brought forth in the following way:

The link between man and the world is broken. Henceforth, this link must become an object of belief... Whether we are Christians or atheists, in our 


\section{Kathrin Thiele}

universal schizophrenia, we need reasons to believe in this world. It is a whole transformation of belief ... to replace the model of knowledge with belief. But belief replaces knowledge only when it becomes belief in this world, as it is. (Deleuze 2000: 172)

In following my argument so far, a misunderstanding could sneak in that is important to avoid, and that-reading this version of the 'belief' statement closely - is addressed explicitly by Deleuze. While his notion of 'belief' can only ever be understood appropriately by linking it to a 'pragmatics'12 such as I have shown above, Deleuze of course also sees the orienting framework of divine providence within this otherwise so worldly American tradition: a latent religiosity which, in the face of writers like Melville, Emerson and Thoreau, surely deserves an appropriate investigation in itself, ${ }^{13}$ but which does not sufficiently transform the concept of belief in order to express what Deleuze is looking for, and thus cannot be taken as the endpoint of the discussion of belief.

Turning to the context of the discussion of 'belief in this world' in Cinema 2, we notice that Deleuze-although in a totally different thematic context-treats the problem of re-inscription of the transcendent into worldliness more thoroughly. The cited passage is taken from a discussion of the cinematographic significance of Roberto Rossellini and Jean-Luc Godard. Addressing again the turn from knowledge to belief, and in precisely the same manner as we saw in the first statement, Deleuze claims that Rossellini 'undoubtedly still retains the ideal of knowledge, he will never abandon this Socratic ideal'. For, ' $[\mathrm{w}] \mathrm{h}$ at made Joan of Arc at the Stake a misunderstood work? The fact that Joan of Arc needs to be in the sky to believe in the tatters of this world. It is from the height of eternity that she can believe in this world' (Deleuze 2000: 172). In contrast to any such transcendent height that safeguards the belief in this world, Godard's work stands alone in enduring an immanence immanent only to itself:

In Godard the ideal of knowledge, the Socratic ideal which is still present in Rossellini, collapses: the 'good' discourse, of the militant, the revolutionary, the feminist, the philosopher, the film-maker, etc., gets no better treatment than the bad. Because the point is to discover and restore belief in the world, before or beyond words. (Deleuze 2000: 172)

The question of belief - of faith, hope and confidence - is, therefore, not as straightforward as it seems at first. We have already established that a rigorous thought of immanence captures everything and leaves nothing to which it could be immanent. Any undemanding belief in this world as harbinger of a better one-at which Deleuze hints with 
his reference to "the "good" discourse, of the militant, revolutionary, feminist, philosopher', in which the divisions between good and evil, right or wrong, have already been decided on-is not at all what is required. His claim of restoring 'belief in the world, before and beyond words' indicates that this notion of belief precisely does not mean an already established 'belief in'. Belief in the Deleuzian sense must be understood as a continuing motor, an activity for keeping the movement which creates ... a world ... becoming-other: no freezing and blocking but endless transformation. Only in this way is the doubling of belief in this second version, according to which 'belief replaces knowledge only when it becomes belief in this world, as it is', fully understandable. The addition to the formula of belief in this version - the 'as it is' - thus makes all the difference. It is not an expression of resignation or an ultimate acceptance of the most visible limits that determine this world, but the paradoxical formulation of the only movement that might lead to real transformation: Active affirmation of 'what is' in order to become inscribed in a dynamic process and thus re-acquire the potential to create something new!

As if the demand for a belief in this world is not already a difficult and ambivalent enough task, Deleuze asks for more. What is needed is a practice that in a most Nietzschean sense 'wills everything all over again'-a belief in this world, as it is. There is to be no other sphere, no better world, providing this one with a saving horizon-such would only set limits to this world (in regard to what it is capable of) and allow for an escape from the bloody here and now. But also no conceptual movement that misunderstands the 'all over again' as 'every time a new beginning'. ${ }^{14}$ Rather, in this kind of belief, what is fundamental is the endless task of repeating and thereby deepening the condition of immanence: We cannot turn back the wheel and will always have to carry on and work from what has already happened.

The task thus always gets more difficult, and Deleuze shows his heritage as a Spinozan realist nowhere better than here: 'To believe in this world, as it is', as a thought of pure immanence, does not mean producing an affirmation of the world according to the ideality of 'what should be'-measuring the possible via the criterion of 'what is', and thus limiting this world from the very start. No, what is truly required is to produce an active affirmation in the face of every single result the world ever takes. Only this way is the becoming-active in and for this world truly never ending; only this way is it an infinite task, ${ }^{15}$ in which mere affirmation of chance becomes active affirmation, and belief in this world-still harbouring the comfort of the transcendent (divine 


\section{Kathrin Thiele}

providence, revolutionary axiomatic or a saving messianism)-becomes a 'belief in this world, as it is'. It is this most demanding realist undertaking that alone leaves open 'what the world is capable of'. ${ }^{16}$

However, given that this is such a difficult thought, and one so easily misread in political terms, it may be helpful to consider yet another context in which Deleuze emphasises the very same realist point. This is Foucault's thought of the outside, as it is treated in Deleuze's study Foucault, where, in reading the latter as a thinker of force-relations, not purely of the rigours of discourse analysis but most significantly of resistances too, Deleuze addresses the specific demand of immanence that concerns us here. When he discusses Foucault's early encounter with the Blanchotian 'thought from outside, ${ }^{17}$ the seemingly all too promising notion of the outside is not to be understood as an outside beyond this world, a realm above or below which grounds it, thereby re-introducing transcendence. On the contrary, the outside is nothing but the other side, the literal outside of the formed strata: '[T]here is nothing lying beneath, above, or even outside the strata. The relations between forces, which are mobile, faint and diffuse, do not lie outside the strata but form the outside of strata' (Deleuze 1988: 84, my emphasis). Counter-intuitive at first but nonetheless most central, Deleuze and Foucault turn the thought of the outside from harbouring a promise of the advent of a better world - separated from the here and now -into the very adventurous process of the here and now itself, utterly immanent and this-worldly. No ticket to another world then, but only negotiations within this world, in the very middle of it, enable openings and niches which - at their best-escape and resist control.

\section{Third Formula of Immanence: Negotiations}

'The belief in this world, as it is' encapsulates the entirety of the complex thought of immanence which Deleuze pursues in all of his philosophical endeavours. His thought-universe is permeated structurally by this ethico-political dimension engaging with this world, and understanding itself as intervening therein. To demonstrate conceptually how the thought of an immanence immanent only to itself, rather than merely contemplating the world, constructs it in every move and gesture it makes, is to refute the argument according to which Deleuze's philosophy only leads us out of this world, with which it ultimately cannot be bothered. However, it would be a mistake to believe that this constitutes an effective response to those voices doubting the legitimacy of Deleuzian (and Foucauldian) thought for our world today. For much 
more is at stake-and here we have to return to our initial starting point and discuss the 'critical arrow' Alain Badiou has fired at Deleuze.

It could be argued that Badiou and Deleuze share extraordinary similarities in terms of their urge to practise philosophy as a form of intervention into this world. In what follows, however, a third version of the Deleuzian belief in this world will be introduced and juxtaposed to a statement by Badiou, in a way that reveals just how far such similarities ultimately turn out to mark deep differences. What will be argued here is that rather than there being a myriad of similarities between Badiou and 'Badiouians' on the one hand and Deleuze and 'Deleuzians' on the other, there is in fact-certain parallels notwithstanding-a major rift between the two thought-universes, a rift that concerns precisely the claim of immanence, which as a starting point for philosophy proper seems to be shared by both thinkers. Likewise, contrary to what is normally claimed on the Badiouian side - that it is Deleuze's thought of immanence which harbours a 'latent religiosity' (Badiou 2008: 387) because of its supposed misconception of the 'event' as 'the fate of the One' (385)-in my view precisely the opposite must be argued. It is Badiou's misconceiving of the thought of multiplicity as a thought of the One, and thus his reification of the virtual into a One, that leads to his opting for the supposedly pure immanence of the multiples, which in turn, however, instead of allowing for a thinking of immanence immanent only to itself, hands it over to a second order, to something that only ever contains immanence. ${ }^{18}$

But we have to move slowly and explain in detail what is at stake here. For the purposes of the present comparison with Badiou, it is best to consider at first only the beginning of Deleuze's third version of the demand for a 'belief in this world'. This is found at the end of a conversation with Antonio Negri in 1990, where Deleuze repeats again what he believes the modern relation to the world to be: 'What we most lack is a belief in the world, we've quite lost the world, it's been taken from us' (Deleuze 1995: 176). If we now turn to look at the epigraph to Badiou's Logics of Worlds, we encounter the exact same diagnosis in regard to the worldly state of affairs. The epigraph-taken from André Malraux's Antimémoires - reads as follows: 'France's agony was not born of the flagging reasons to believe in her-defeat, demography, industry, etc. - but of the incapacity to believe in anything at all.' (Badiou 2008: 1).

The same beginning, then - but what follows? Let us turn to Deleuze and see how he proceeds. After having stated that '[w]hat we most lack is a belief in the world, we've quite lost the world, it's been taken from us', he continues: 'If you believe in the world you precipitate events, 


\section{Kathrin Thiele}

however inconspicuous, that elude control, you engender new spacetimes, however small their surface or volume... Our ability to resist control, or our submission to it, has to be assessed at the level of our every move' (Deleuze 1995: 176). As we can see, in Deleuze's 'belief' there is no new collective imaginary (a One) from where and towards which our becoming-active is and ever will be legitimised; rather, the political impetus expressed here is no more, but also no less, than a most singular movement 'assessed at the level of our every move'. Only in this way is immanence not impeded, the world not blocked, such that everything becomes-transformed. Such active belief is apparently also nothing particularly grand. Most of the time-as the explications in this passage show - it is a very 'inconspicuous' and 'small' undertaking. It is thus to affirm and to become-active, but in a most moderate and indeed negotiable way. It is, as Gregg Lambert once described it:

the affirmative principle... [that] can be understood as the most sobering response to this predicament: to believe in this world, as it is, neither in a transformed world, nor in another world, and to provide an image of thought that thoroughly belongs to this world which is ruled by the powers of the false; moreover to raise falsehood to a positive principle in the service of those who choose to live in this world and not in another... Restoring our connection to the world, but also assuming a constant vigilance over clichés and ready-made linkages. (Lambert 2002: 131)

A political horizon based on falsehood, negotiations and singular movements cannot but stand in opposition to Alain Badiou's rigid and truthful political vision. In Badiou's eyes it is precisely such 'contemporary doxa' (Badiou 2008: 2) that reduces the world to the political fallacies and lethargies of the majoritarian 'democratic materialism' in which 'the logic of the One' and, following from there, 'this sovereignty of the Two (bodies and languages)', rules, and to which he so strongly opposes a 'materialist dialectic' in whose formula the category of truth-although pluralised-reappears: 'There are only bodies and languages, except that there are truths' (4). ${ }^{19}$

While it cannot but remain a matter of ongoing debate just how a Deleuzian point of view in regard to political action differs in kind from a Badiouian one,${ }^{20}$ one fact seems unambiguous: Badiou's claim to a renewed 'Politics of Truths', but also his harsh critique of all non-universal political formations from which he delimits a 'new universalism', underline the categorical differences at stake here. ${ }^{21}$ While at first it seems to be a merely political dispute over the best or most appropriate strategy to adopt, what we are facing here is in fact more 
fundamental, revealing a principal difference in regard to the question of how thought and practice are interrelated. To unfold this categorical difference will form the last step of the present argument.

\section{Spinoza's Heritage}

What has been shown so far is that according to Deleuze's philosophy thought is always already thought as practice. It is a practice of actual construction, whose significance shows itself in every instance. The 'ability to resist control' (inasmuch as the 'submission to it') is to be 'assessed at the level of our every move'. The construction and practice of this world is everything, for the world 'is' nothing but politics. In staging the political problem thus, giving practice preference over truths, Deleuze, rather than weakening his thought into 'a poor man's Spinozism', rigorously continues what a thought of immanence immanent only to itself ever demands.

To envision politics again as 'knowing', as a prescriptive 'Politics of Truths' striving for axiomatic principles (and thereby clearly opposing what Foucault meant when he defined philosophy as a 'politics of truth'), is both conceptually undermining of the thought of immanence and practically counter-productive. What cannot be avoided in this rectification of politics is the re-introduction of transcendent principles (universals, truths) that pre-determine the political terrain and thus stop movement, freeze the world, and become yet another variation of the kind of politics of which Foucault was so weary, that (political) business as usual which he rejects by postulating: 'Never do Politics!'

Instead, in a truly immanent thought, one that pursues this demand also into practice, the political question itself must change. Rather than a credo that is to be 'followed' it must become first a question of analysis (of that which 'is' the world-in A Thousand Plateaus Deleuze and Guattari call this an a-signifying semiotics) and second, on a more affective level, a carrying forward of the movement of immanence, that is 'a belief in this world, as it is' as the only condition for a different future. A becoming-active as political activism cannot be based on the-however rigorous - renewal and restoration of categories such as universalism and truth, which are to be followed with the same categorical fidelity that any knowing 'believing in' has always prescribed. To the contrary, 'belief in the world, as it is', according to Deleuze, must remain a fully immanent process of experimentation - an open-ended process that only ever constitutes itself parallel to what it experiences; an experimentation, however, that is to be understood in a most sober sense, a negotiating 


\section{Kathrin Thiele}

from within. His epigraph to Pourparlers clarifies this:

Philosophy isn't a Power. Religions, states, capitalism, science, the law, public opinion, and television are powers, but not philosophy. Philosophy may have its great internal battles (between idealism and realism, and so on), but they're mock battles. Not being a power, philosophy can't battle with the powers that be, but it fights a war without battles, a guerrilla campaign against them. And it can't converse with them, it's got nothing to tell them, nothing to communicate, and can only negotiate. Since the powers aren't just external things, but permeate each of us, philosophy throws us all into constant negotiations with, and a guerrilla campaign against, ourselves. (Deleuze 1995: epigraph)

If we let immanence capture everything, then every philosophical endeavour will be just as much entangled with politics in so far as the ethico-political is always already present in even the purest ontological undertaking. Rather than presupposing a descriptive ontological axiomatic from which a prescriptive politics follows, Deleuze claims that we have to endure entanglements if we are to claim to follow through a thought of immanence immanent only to itself. The political question today will not find an effective response without changing what it is that is being questioned. Foucault saw this in one of his interviews from 1984, when asked by Paul Rabinow what his own stand towards politics was:

I have never tried to analyze anything whatsoever from the point of view of politics, but always to ask politics what it had to say about the problems with which it was confronted. I question it about the positions it takes and the reasons it gives for this; I don't ask it to determine the theory of what I do. I am neither an adversary nor a partisan of Marxism; I question it about what it has to say about experiences that ask questions of it. (Foucault 1997a: 115)

While Deleuze's thought puts more emphasis on potential resistances, the openings of lines of flight and of escapes, ${ }^{22}$ he nonetheless follows this cautious Foucauldian line whenever he speaks of politics in the concrete, that is, in its actuality. The non-unifiable concept of the 'body without organs' illustrates this just as much as the deterritorialising series of 'becomings' developed in A Thousand Plateaus. Rather than judging such caution as revealing a weak approach to political actuality, it is up to us finally to learn that this indirect approach is precisely not an escape from the world but a rigorous transformation of the question of politics according to the practice of a thought that affirms its absolute immanence. Whoever we are, we need reasons to believe in this world. It is, however, important to realise fully the inexistence of any dative whatsoever that could contain this immanence. Instead of again referring to nameable truths, we have to learn to turn the question, and with it the 
apparent political vacuum, into a practice that-at its best-confirms a belief in this world, as it is, wherein our ability to resist will be assessed on the level of our every move.

It is here that one last time we come up against the significant heritage of Spinoza. The Spinoza who not only is the prince of philosophy when it comes to the question of immanence but who is also the principal point of reference when it comes to both entangling and disentangling the questions of ontology, ethics and politics. And while both Badiou and Deleuze share this heritage, Spinoza at the same time represents the line of delimitation that must be drawn between them. For, whereas Deleuze values Spinoza's affective realism as fundamental to an understanding of the latter's metaphysical and political system, it is Spinoza's rigour in the mathematisation of the world that Badiou clearly favours (and where he ultimately also sees his limits). While it is much too early to jump to the conclusion that it is precisely because of these two different Spinozas that we find such different political agendas in the two philosophers-one prescriptive and the other, as I have called it, realistic - what can definitely be concluded at this moment is that it is because of Badiou's negligence of Spinoza's theory of affects that he must ultimately criticise and reject Spinoza as a metaphysical thinker who forecloses 'the void' - which, according to Badiou, alone represents the possibility 'of thinking multiplicity, on the one hand, and novelty, on the other' (Gillespie 2001: 63). The debate over the relation between the philosophical claim of immanence and the quest for political activism here reaches another level of sophistication that will require further analysis. My aim in this article was to reach this point. Right now, the quest to link immanence and politics unfolds in two diverging directions: either formalisation (Badiou) or actualisation (Deleuze); that is, radical fidelity to the axioms of truths and universality on the one hand and active experimentation with resistances and negotiations on the other.

\section{Notes}

1. I am especially indebted to Deleuzian scholars such as Braidotti, Grosz, Marrati and Patton who in regard to the question of politics not only illuminate Deleuze's thought but also push his thinking in fruitful new directions.

2. I have also developed this demand of philosophical thought as 'active thought' in my book The Thought of Becoming: Gilles Deleuze's Poetics of Life (Thiele 2008).

3. Interview with Catherine Clément, 'Entretien 1980', L'Arc, 49, cited in Patton 1984.

4. The reference to a 'Spinozan realism' will recur in this article. It is most clearly articulated in the famous beginning of Spinoza's Tractatus Politicus 


\section{Kathrin Thiele}

(1677) in which the philosophical temptation to approach the subject matter in question (in Spinoza's case 'men') 'not as they are, but as they [the philosophers] themselves would like them to be' is rejected and a realist approach to 'what is'-'not what is new and unheard of, but only such things as agree best with practice' - is taken as the only valid method for an effective conceptual investigation (Spinoza 1956: Introduction).

5. While the formula 'always already yet never once and for all' cannot rid itself completely from the Heideggerian 'always already' as it determines Heidegger's definition of Dasein as 'always already ahead of itself', here it rather stands for the attempt to bring to language the logic of repetition in difference that is the beginning (without beginning) of Deleuze's thought-practice as such: 'the repetition of an internal difference which it incorporates in each of its moments, and carries from one distinctive point to another' (Deleuze 1994: 20).

6. Cf. also Paul Patton: 'Nomadology certainly does not offer any political program, any more than did schizoanalysis. Nor does it offer any straightforward political morality, in the sense of imperatives addressed to subjects ... the question is never simply one of good or bad, but of the specificity of each case... It is a matter of assessing the qualities present in a given situation or the true nature of a given process: is it a creative or a destructive line?' (Patton 1984: 79-80).

7. The French version says: 'Je ne proposerai donc en tout ceci qu'un seul impératif, mais celui-là sera catégorique et inconditionnel: ne faire jamais de politique' (Foucault 2004: 6). In the English edition of the lectures, the expression 'ne faire jamais de politique' is, however, translated as 'never engage in polemics' (cf. Foucault 2009: 4). While, considering the actual context, the translation seems possible, Foucault's having meant 'politics' is, of course, much more provocative than if he had merely stated - in a real philosophical manner-that one should not engage in polemics. Since for my purposes it is important to push Deleuze and Foucault as far as possible on this, I take the French 'politique' to translate as 'politics', no matter that, for example, in the interview 'Polemics, Politics, and Problematization' from 1984, the first question Paul Rabinow asks is the following: 'Why is it that you don't engage in polemics?' - an apparent repetition of Foucault's 1978 'categorical imperative'. See Foucault 1997a.

8. This 'beyond' must of course not be read in a Levinasian sense, in which it signifies a gesture towards (necessary) transcendence-absolute Otherness.

9. 'The virtue in most request is conformity. Self-reliance is its aversion', says Emerson in one of his most important essays (Emerson 1983: 261). Given Deleuze's many references to the Anglo-American tradition, its 'superiority' in what concerns literature (cf. Deleuze and Parnet 2002: 36-76), and the pervasive re-turn to an empiricist line of thought originating in William James' radical empiricism (cf. e.g. Deleuze 1997: 68-90, esp. pp. 88ff), reading the 'empiricist conversion' in such an 'American way' is not too far fetched.

10. For both the central notion of belief in James and his radical empiricism, cf. his famous essay 'The Will to Believe' (James 1956: 1-31), and his Essays in Radical Empiricism (James 2003).

11. 'What the world is capable of' is not merely another phrasing of the usual moral of 'what should be', as it can be found in most (post-Kantian) practical philosophy. The latter refers the 'what is' to something else - 'a dative' as Deleuze and Guattari say - and thus reintroduces the transcendent, while 'what the world is capable of' enacts the Spinozan credo of a logic of pure force-relations.

12. Deleuze and Guattari use this term to name their politico-philosophical undertaking in A Thousand Plateaus. 
13. Cf. Branka Arsić's work on the American literary and philosophical tradition (Arsić 2007, 2010).

14. Such as, for example, Hannah Arendt would have it in a Augustinian heritage. Cf. her dissertation on St Augustine from 1929 (Arendt 1998).

15. For the characterisation of philosophical thought as an 'infinite task', cf. Gasché 2007, in which he also discusses Deleuze as 'Thinking Within Thought'. Cf. also his most recent study on Europe, or The Infinite Task (Gasché 2009).

16. Again, it is important to refer here directly to Spinoza's Tractatus Politicus which, read in conjunction with his Ethics, effectuates precisely such a construction: a most rigorous affirmation of 'what is', based on the premise that 'what is' is a measure of power and not essence, for 'no one has so far determined what the body can do'. For Spinoza's discussion of natural right in the Political Treatise cf. Spinoza 1956: ch. II; and with regard to his central statement from The Ethics see Spinoza 2000: EIIIP2 S.

17. On the thought of the outside, cf. Foucault $1997 \mathrm{~b}$.

18. For a more detailed discussion of the diverging lines of thought of Badiou and Deleuze in regard to 'immanence' and 'ontology', leading into a discussion of how to understand the different/ciation of virtual/actual in Deleuze, cf. Thiele 2008: especially part V, 164ff.

19. While in the argument developed here the categorical concept of 'truths'reintroduced into the domain of both philosophy and politics by Badiou-is contested because of its conceptual shortcomings in the face of a political thought based on immanence, Badiou's extrapolation of the problem alongside Descartes' early 'intuition of the same order regarding the ontological status of truths' (Badiou 2008: 5) is a most fruitful discussion of how the concept of truth/s could be torn away from a far too reductive positivist category, to be thought as 'generic multiplicities' (6).

20. One of the clearest discussions of the differences between Badiou and Deleuze can be found in Sam Gillespie's Mathematics of Novelty: Badiou's Minimalist Metaphysics (Gillespie 2008). For the same cluster of questions, this time also in respect to their readings of Spinoza, cf. Gillespie 2001.

21. For Badiou's well-elaborated political thought in which the categories of truth(s) and universality play a most significant role, see especially Badiou 2003 and 2005.

22. This is what especially the feminist legacy in Deleuzian scholarship (Braidotti, David-Ménard, Grosz, Marrati, to name just a few) has most poignantly shown by engaging with the Deleuzian concepts of difference, immanence, nomadology and bodies. Instead of painting yet another grand picture of thought beyond different/ciation, theirs is the task of furthering and carrying forward this condition for a different future. To give just one example (from Elizabeth Grosz): '[F]eminist politics should, I believe, now consider the affirmation of a politics of imperceptibility, leaving its traces and effects everywhere but never being able to be identified with a person, group, or organization. It is not a politics of visibility, or recognition and of self-validation, but a process of self-marking that constitutes oneself in the very model of that which oppresses and opposes the subject' (Grosz 2005: 194).

\section{References}

Arendt, Hannah (1998) Love and Saint Augustine, ed. Joanna Vecchiarelli Scott and Judith Chelius Stark, Chicago: University of Chicago Press.

Arsić, Branka (2007) Passive Consititutions; or 71/2 times Bartleby, Stanford, CA: Stanford University Press. 


\section{Kathrin Thiele}

Arsić, Branka (2010) On Leaving: A Reading in Emerson, Cambridge, MA: Harvard University Press.

Badiou, Alain (2005) Metapolitics, trans. Jason Barker, London and New York: Verso.

Badiou, Alain (2007) Saint Paul: The Foundation of Universalism, trans. Ray Brassier, Stanford, CA: Stanford University Press.

Badiou, Alain (2009) Logic of Worlds: Being and Event II, trans. Alberto Toscano, New York and London: Continuum.

Deleuze, Gilles (1994) Difference and Repetition, trans. Paul Patton, New York: Columbia University Press.

Deleuze, Gilles (1995) Negotiations: 1972-1990, trans. Martin Joughin, New York: Columbia University Press.

Deleuze, Gilles (1997) Essays Critical and Clinical, trans. Daniel Smith and Michael Greco, Minneapolis: University of Minnesota Press.

Deleuze, Gilles (1988) Foucault, trans. Sean Hand, Minneapolis: University of Minnesota Press.

Deleuze, Gilles (2000) Cinema 2: The Time-Image, trans. Hugh Tomlinson and Robert Galeta, London: Athlone Press.

Deleuze, Gilles and Félix Guattari (1994) What is Philosophy?, trans. Hugh Tomlinson and Graham Burchell, Minneapolis: University of Minnesota Press.

Deleuze, Gilles and Félix Guattari (2000) A Thousand Plateaus, trans. Brian Massumi, Minneapolis: University of Minnesota Press.

Deleuze, Gilles and Claire Parnet (2006) 'On the Superiority of Anglo-American Literature', in Dialogues II, trans. Hugh Tomlinson and Barbara Habberjam, New York and London: Continuum, pp. 27-56.

Emerson, Ralph Waldo (1983) 'Self-Reliance', in Essays and Lectures: First and Second Series, New York: The Library of America, pp. 259-82.

Foucault, Michel (1997a) 'Polemics, Politics and Problematization', in Ethics: Subjectivity and Truth: Essential Works of Foucault, vol. 1, New York: The New Press, pp. 111-20.

Foucault, Michel and Maurice Blanchot (1997b) Foucault/Blanchot: Maurice Blanchot: The Thought from Outside and Michel Foucault As I Imagine Him, New York: Zone Books.

Foucault, Michel (2004) Sécurité, Territoire, Population. Cours au Collège de France, 1977-1978, Paris: Gallimard/Seuil.

Foucault, Michel (2009) Security, Territory, Population. Lectures at the Collège de France 1977-1978, trans. Graham Burchell, New York: Palgrave Macmillan.

Gasché, Rodolphe (2007) The Honor of Thinking: Criticism, Theory, Philosophy, Stanford, CA: Stanford University Press.

Gasché, Rodolphe (2009) Europe, or the Infinite Task, Stanford, CA: Stanford University Press.

Gillespie, Sam (2001) 'Placing the Void. Badiou on Spinoza', Angelaki, 6:3, pp. 63-77.

Gillespie, Sam (2008) Mathematics of Novelty: Badiou's Minimalist Metaphysics, Melbourne: re.press.

Grosz, Elizabeth (2005) Time Travels: Feminism, Nature, Power, Durham and London: Duke University Press.

Hallward, Peter (2006) Out of This World: Deleuze and the Philosophy of Creation, London and New York: Verso.

James, William (1956) The Will to Believe and Other Essays in Popular Philosophy, New York: Dover Press.

James, William (2003) Essays in Radical Empiricism, New York: Dover Press. 
Lambert, Gregg (2002) The Non-Philosophy of Gilles Deleuze, New York and London: Continuum.

Patton, Paul (1984) 'Conceptual Politics and the War-Machine in Mille Plateaux', SubStance, 13:44-5, pp. 60-81.

Spinoza, Baruch de (1956) A Theologico-Political Treatise and A Political Treatise, ed. and trans. R.H.M. Elwes, New York: Dover Press.

Spinoza, Baruch de (2000) The Ethics, ed. and trans. G.H.R. Parkinson, Oxford: Oxford University Press.

Thiele, Kathrin (2008) The Thought of Becoming: Gilles Deleuze's Poetics of Life, Berlin/Zürich: Diaphanes Verlag. 